\title{
Biomarkers of Alzheimer Disease in Plasma
}

\author{
Michael C. Irizarry \\ Alzheimer Disease Research Unit, Department of Neurology, Massachusetts General Hospital, Charlestown, \\ Massachusetts 02129
}

\begin{abstract}
Summary: Plasma and serum biochemical markers proposed for Alzheimer disease (AD) are based on pathophysiologic processes such as amyloid plaque formation [amyloid $\beta$-protein $(\mathrm{A} \beta), \mathrm{A} \beta$ autoantibodies, platelet amyloid precursor protein (APP) isoforms], inflammation (cytokines), oxidative stress (vitamin E, isoprostanes), lipid metabolism (apolipoprotein E, 24S-hydroxycholesterol), and vascular disease [homocysteine, lipoprotein (a)]. Most proteins or metabolites evaluated in plasma or serum thus far are, at best, biological correlates of $\mathrm{AD}$ : levels are statistically
\end{abstract}

different in $\mathrm{AD}$ versus controls in some cohorts, but they lack sensitivity or specificity for diagnosis or for tracking response to therapy. Approaches combining panels of existing biomarkers or surveying the range of proteins in plasma (proteomics) show promise for discovering biomarker profiles that are characteristic of $\mathrm{AD}$, yet distinct from nondemented patients or patients with other forms of dementia. Key Words: Biomarkers, amyloid $\beta$-protein, isoprostanes, homocysteine, 24S-hydroxycholesterol, cytokines, proteomics.

\section{INTRODUCTION}

The profound biochemical and pathological alterations in the Alzheimer disease (AD) brain result from cellular processes such as amyloid precursor protein (APP) and amyloid $\beta$-protein $(\mathrm{A} \beta)$ metabolism, tau phosphorylation, oxidative stress, inflammation, and lipid dysregulation. Biomarkers of $\mathrm{AD}$ are intended to detect these features of $\mathrm{AD}$ pathophysiology in biological fluids. Cerebrospinal fluid (CSF) closely reflects the composition of the brain extracellular space, and is likely to have the highest yield in biomarker evaluation, as described by Blennow in the present issue of NeuroRx ${ }^{\circledR}(1: 213-225$, 2004.) Nonetheless, CSF is not routinely collected in the evaluation of $\mathrm{AD}$, and lumbar puncture is not a widespread procedure in primary care, psychiatric practices, and geriatric practices that often care for $\mathrm{AD}$ patients. The identification of biomarker molecules in blood would be more widely applicable, and reduce the need for invasive, expensive or time-consuming testing.

$\mathrm{AD}$ is a challenging disease for the development of biomarkers. The assessment of AD biomarkers is complicated by diagnostic imprecision, the long asymptomatic

Address correspondence and reprint requests to Dr. Michael Irizarry, Alzheimer Disease Research Unit, Massachusetts General HospitalEast, Building 114, Room 2010, 114 16th Street, Charlestown, MA 02129. E-mail: mirizarry@ partners.org. prodromal stages, variability in clinical features and rates of progression, complex disease genetics and multiple molecular etiologies [e.g., presenilin-1 ( $P S-1)$, presenilin-2 $(P S-2)$, and $A P P$ mutations; apolipoprotein E (APOE) allelic polymorphisms; and sporadic $\mathrm{AD}]$. Additional issues arise in the case of serum or plasma biomarkers of $\mathrm{AD}$ relative to CSF. The physiology of the blood-brain barrier may limit potential diagnostic biomarkers to small molecules, lipophilic molecules, or molecules with specific transporters. Brain proteins and metabolites that pass into the plasma become markedly diluted into a biochemically complex medium.

This paper reviews proposed serum and plasma biomarkers for $\mathrm{AD}$, focusing on markers of APP processing but also assessing measures of lipid metabolism, oxidation, and inflammation. Because the currently available measures lack high sensitivity and specificity for $\mathrm{AD}$ diagnosis, the paper concludes with a discussion of strategies for novel biomarker discovery.

\section{MARKERS RELATED TO APP AND A $\beta$ METABOLISM}

\section{Amyloid $\beta$-protein}

Because amyloid plaques are a defining feature of $\mathrm{AD}$ neuropathology, and $\mathrm{A} \beta$ can be detected in CSF and plasma, $\mathrm{A} \beta$ measures in biological fluids are compelling candidate biomarkers for $\mathrm{AD} .^{1} \mathrm{~A} \beta$ occurs in two prominent forms, containing $40(\mathrm{~A} \beta 40)$ or $42(\mathrm{~A} \beta 42)$ amino 
TABLE 1. Plasma and Serum AB Levels in $A D$

\begin{tabular}{|c|c|c|c|c|c|c|}
\hline \multirow{3}{*}{$\begin{array}{l}\begin{array}{l}\text { First Author } \\
\text { [reference] }\end{array} \\
\text { Scheuner [5] }\end{array}$} & \multirow{3}{*}{$\begin{array}{c}\text { Assay Antibodies } \\
\text { A } \beta \text { capture } \\
\text { (epitope) } \\
\text { A } \beta-40 / \mathrm{A} \beta 42 \\
\text { BAN50 (A } \beta 1-16) \\
\text { BA27/BC05 }\end{array}$} & \multirow{3}{*}{\begin{tabular}{l}
\multicolumn{1}{c}{ Diagnosis } \\
AD \\
Control
\end{tabular}} & \multirow{3}{*}{$\begin{array}{l}N \\
71 \\
75\end{array}$} & $\mathrm{~A} \beta 40$ & $\mathrm{~A} \beta 42$ & \multirow{3}{*}{$\begin{array}{c}\text { Results } \\
\text { No difference by diagnosis }\end{array}$} \\
\hline & & & & \multicolumn{2}{|c|}{$(\mathrm{pmol} / \mathrm{L} \pm \mathrm{SEM})$} & \\
\hline & & & & $\begin{array}{l}190 \pm 5^{*} \\
200 \pm 10^{*}\end{array}$ & $\begin{array}{l}29 \pm 2 \\
27 \pm 3\end{array}$ & \\
\hline Tamaoka $^{\dagger}[8]$ & $\begin{array}{l}\text { BAN50 (A } \beta 1-16) \\
\text { BA27/BC05 }\end{array}$ & $\begin{array}{l}\text { AD } \\
\text { Control } \\
\text { Neurological } \\
\quad \text { control }\end{array}$ & $\begin{array}{l}28 \\
25 \\
40\end{array}$ & $\begin{array}{l}70.6 \pm 7.9 \\
68.6 \pm 4.2 \\
63.4 \pm 4.0\end{array}$ & $\begin{array}{l}61.3 \pm 7.6 \\
43.1 \pm 5.1 \\
57.6 \pm 5.7\end{array}$ & No difference by diagnosis \\
\hline Kosaka $^{\dagger}[6]$ & $\begin{array}{l}\text { BNT77 (A } \beta 11-28) \\
\text { BA27/BC05 }\end{array}$ & $\begin{array}{l}\mathrm{AD} \\
\text { Control } \\
\begin{array}{c}\text { Neurological } \\
\quad \text { control }\end{array}\end{array}$ & $\begin{array}{l}44 \\
15 \\
22\end{array}$ & $\begin{array}{l}68.7 \pm 1.7 \\
77.6 \pm 2.5 \\
74.1 \pm 0.6\end{array}$ & $\begin{array}{r}9.8 \pm 0.5 \\
10.7 \pm 0.5 \\
10.3 \pm 0.6\end{array}$ & $\begin{array}{l}\text { No difference by diagnosis } \\
\text { No effect of disease stage }\end{array}$ \\
\hline Mayeux & $\begin{array}{l}\text { 6E10 (A } \beta 1-16) \\
\text { R162/R165 }\end{array}$ & $\begin{array}{l}\text { Incipient AD } \\
\text { Control }\end{array}$ & $\begin{array}{r}64 \\
105\end{array}$ & $\begin{array}{l}38.3 \pm 1.6^{\S} \\
31.8 \pm 1.2\end{array}$ & $\begin{array}{l}23.4 \pm 2.4^{\S} \\
14.6 \pm 1.2^{\S}\end{array}$ & $\begin{array}{l}\text { Increased } \mathrm{A} \beta 40 \text { and } \mathrm{A} \beta 42 \\
\text { with age and incipient } \mathrm{AD} \\
\text { No effect of diagnosis on } \\
\text { rate of change } \\
\text { No effect of sex, } A P O E, \\
\text { family history of } \mathrm{AD}\end{array}$ \\
\hline Mehta $^{\dagger+}[10]$ & $\begin{array}{l}\text { 6E10 (A } \beta 1-16) \\
\text { R162/R164 }\end{array}$ & $\begin{array}{l}\mathrm{AD} \\
\text { Control }\end{array}$ & $\begin{array}{l}78 \\
61\end{array}$ & $\begin{array}{l}77.2(28-219)^{\mathrm{IL}} \\
62.2(10-139)^{\mathrm{I}}\end{array}$ & $\begin{array}{l}20.7(7-250)^{\mathrm{qI}} \\
23.0(7-257)^{\mathrm{II}}\end{array}$ & $\begin{array}{l}\text { Increased } \mathrm{A} \beta 40 \text { in } \mathrm{AD} \\
\text { Increased } \mathrm{A} \beta 40 \text { with age } \\
\text { No effect of sex or MMSE }\end{array}$ \\
\hline Vanderstichele $\mathrm{e}^{\dagger \neq}[11]$ & $\begin{array}{l}\text { 3D6 }(\mathrm{A} \beta 1-5) \\
21 \mathrm{~F} 12(\mathrm{~A} \beta 42)\end{array}$ & $\begin{array}{l}\text { AD } \\
\text { Control } \\
\text { DLB } \\
\text { Nondemented } \\
\text { Other dementia }\end{array}$ & $\begin{array}{r}39 \\
12 \\
6 \\
9 \\
10\end{array}$ & & $\begin{array}{l}34.4 \pm 2.5 \\
40.9 \pm 8.5 \\
36.1 \pm 2.9 \\
31.5 \pm 1.6 \\
40.0 \pm 7.2\end{array}$ & $\begin{array}{l}\text { No difference by diagnosis } \\
\text { No effect of sex or MMSE }\end{array}$ \\
\hline Fukumoto [12] & $\begin{array}{l}\mathrm{BNT77}(\mathrm{A} \beta 11-28) \\
\mathrm{BA} 27 / \mathrm{BC} 05\end{array}$ & $\begin{array}{l}\text { AD } \\
\text { MCI } \\
\text { PD } \\
\text { Control }\end{array}$ & $\begin{array}{r}146 \\
37 \\
96 \\
92\end{array}$ & $\begin{array}{l}52.4 \pm 1.4 \\
47.8 \pm 2.5 \\
48.0 \pm 1.8 \\
48.9 \pm 1.8\end{array}$ & $\begin{array}{l}7.4 \pm 0.4 \\
6.5 \pm 0.5 \\
7.0 \pm 0.3 \\
7.0 \pm 0.3\end{array}$ & $\begin{array}{l}\text { No difference by diagnosis } \\
\text { Increased } \mathrm{A} \beta 40 \text { and } \mathrm{A} \beta 42 \\
\text { with age } 37 \\
\text { No effect of medications, } \\
A P O E \text {, severity or duration } \\
\text { of dementia }\end{array}$ \\
\hline Mayeux $^{\dagger \neq}[13]$ & $\begin{array}{l}\text { 6E10 (A } \beta 1-16) \\
\text { R162/R165 }\end{array}$ & $\begin{array}{l}\mathrm{AD} \text { at baseline } \\
\text { Incident } \mathrm{AD} \\
\text { Nondemented }\end{array}$ & $\begin{array}{r}79 \\
86 \\
365\end{array}$ & $\begin{array}{l}43.6 \pm 1.5 \\
38.7 \pm 1.4 \\
37.9 \pm 0.9\end{array}$ & $\begin{array}{l}19.5 \pm 0.8^{\S} \\
21.7 \pm 1.8^{\S} \\
21.7 \pm 1.8^{\S} \\
16.7 \pm 0.5\end{array}$ & $\begin{array}{l}\text { Increased } \mathrm{A} \beta 42 \text { in } \mathrm{AD} \text { and } \\
\text { incident } \mathrm{AD} \\
\text { Decline in } \mathrm{A} \beta 42 \text { over } 3 \\
\text { years in incident } \mathrm{AD} \\
\text { Increased } \mathrm{A} \beta 40 \text { and } \mathrm{A} \beta 42 \\
\text { with age } \\
\text { Inverse relation between } \\
\mathrm{A} \beta 40 \text { and cholesterol } \\
\text { No effect of } A P O E\end{array}$ \\
\hline
\end{tabular}

*Estimated from graph.

${ }^{\dagger}$ SEM calculated from SD and $N$.

${ }^{\ddagger} \mathrm{A} \beta$ values converted from $\mathrm{pg} / \mathrm{ml}$ to $\mathrm{pmol} / \mathrm{L}(1 \mathrm{pg} / \mathrm{ml}=0.284 \mathrm{pmol} / \mathrm{L})$.

${ }_{\S}^{\S}$ Statistically significant difference relative to control group.

${ }^{\text {II }}$ Median (range).

$\mathrm{DLB}=$ dementia with Lewy bodies; $\mathrm{MCI}=$ mild cognitive impairment; $\mathrm{PD}=$ Parkinson disease; MMSE $=$ Mini-Mental State Examination .

acids depending on the $\mathrm{C}$ terminus (although various $\mathrm{N}$-terminally truncated forms also occur). $\mathrm{A} \beta 42$ is the initial species deposited in brain, and is more toxic and fibrillogenic in vitro..$^{2-4}$ The development of sensitive ELISAs for $A \beta 40$ and $A \beta 42$ enabled the detection and quantitation of $\mathrm{A} \beta$ in human blood. Plasma total $\mathrm{A} \beta$ or $\mathrm{A} \beta 42$ was increased in familial $\mathrm{AD}$ with presenilin or $A P P$ mutations as well as in Down syndrome with $A P P$ triplication, ${ }^{5-7}$ raising the possibility that sporadic cases of $\mathrm{AD}$ might be associated with detectable and diagnostic changes in the plasma levels of $\mathrm{A} \beta$.
Several cross-sectional studies and two longitudinal studies investigated plasma $\mathrm{A} \beta$ measures in $\mathrm{AD}$ (Table 1)..$^{5,6,8-13} \mathrm{~A} \beta 40$ was elevated in a study of $78 \mathrm{AD}$ and 61 control cases ${ }^{10}$; however, most groups have found no significant differences between $\mathrm{AD}$ and control cases. ${ }^{5,6,8,11,12} \mathrm{~A} \beta 40$ and sometimes $\mathrm{A} \beta 42$ levels correlated strongly with age $e^{9,12-14}$ and with serum creatinine levels. ${ }^{15}$ The broad overlap in plasma $A \beta$ levels between $\mathrm{AD}$ and control cases indicates that plasma $\mathrm{A} \beta$ cannot reliably differentiate sporadic $\mathrm{AD}$ from control cases in a cross-sectional study. 
Although not diagnostically useful, plasma $\mathrm{A} \beta$ measures can also be evaluated in the context of AD prediction, progression, and therapeutic monitoring. Two longitudinal studies suggested that high plasma $\mathrm{A} \beta 42$ levels were a risk factor for developing AD. In a study of 169 nondemented individuals with mean age 74.9 years, those who developed AD during an average follow-up of 3.6 years had higher baseline plasma $\mathrm{A} \beta 42$ levels; in individual patients, plasma $\mathrm{A} \beta 42$ levels declined by an average of $3 \%$ and $A \beta 40$ levels by $12 \%$ over $3-4$ years, independent of the development of AD. ${ }^{9}$ In the Northern Manhattan Aging Study, individuals with AD at baseline or who developed AD within 5 years after plasma collection had higher levels of plasma $\mathrm{A} \beta 42$ than individuals who remained nondemented; plasma $\mathrm{A} \beta 42$ declined more rapidly over 3 years in individuals who developed $\mathrm{AD}$ during the follow-up period. ${ }^{13}$ In cross-sectional studies, though, plasma $A \beta$ levels did not correlate with measures of progression or dementia severity. ${ }^{10,12,16}$

Plasma $\mathrm{A} \beta$ measures are potentially useful in clinical studies as markers of the pharmacological effects of medications that affect APP processing. For example, reduction in plasma $A \beta$ levels with treatment could confirm the mechanism of action of medications that inhibit the $\beta$-secretase or $\gamma$-secretase that produces $A \beta$. Crosssectional studies found no significant effects of statins, estrogen, non-steroidal anti-inflammatory drugs, antioxidants, or cholinesterase inhibitors on plasma $\mathrm{A} \beta$ levels. ${ }^{12,17}$ In contrast, in double-blind placebo-controlled studies, lovastatin reduced plasma $\mathrm{A} \beta$ levels over 3 months, ${ }^{18}$ and transdermal $17 \beta$-estradiol was associated with a reduction of plasma $A \beta 40$ over 8 weeks in a small subset of estrogen-naïve patients. ${ }^{19}$ As a surrogate marker for therapeutics, medication-related changes in plasma $\mathrm{A} \beta$ levels do not necessarily imply clinical benefit, because plasma $\mathrm{A} \beta$ levels correlate poorly with severity of dementia.

Thus, plasma $A \beta$ measures are not sensitive or specific markers for the diagnosis of AD. Increasing $A \beta$ species in plasma with aging may be a peripheral reflection of the balance between $\mathrm{A} \beta$ production and clearance that in the brain contributes to age-related $\mathrm{A} \beta$ deposition and $\mathrm{AD}$ risk. Further study is required to clarify the role of plasma $\mathrm{A} \beta$ as a biomarker for predicting $\mathrm{AD}$ risk, tracking progression, and following the effectiveness of medications.

\section{Brain-plasma A $\boldsymbol{\beta}$ flux}

CSF $A \beta$ levels do not correlate with plasma $A \beta$ levels in individual patients ${ }^{11,16}$; even in APP transgenic mice, plasma $A \beta$ levels do not correlate with biochemical or pathological measures of cerebral $\mathrm{A} \beta$ deposition. ${ }^{20}$ Nonetheless, animal studies indicate that $\mathrm{A} \beta$ can pass between the CSF and plasma compartments. ${ }^{21,22}$ Peripherally administered compounds with high-affinity bind- ing to $\mathrm{A} \beta$ increased the flux of $\mathrm{A} \beta$ from the brain and CSF to the plasma in APP transgenic mice..$^{20,23}$ The amount of $\mathrm{A} \beta$ appearing in the plasma after administration of an anti-A $\beta$ antibody to APP transgenic mice correlated strongly with hippocampal and cingulate amyloid deposition, as well as total brain $\mathrm{A} \beta$ by ELISA. If confirmed in humans, measures of brain-to-plasma $A \beta$ efflux could be a peripheral indicator of the extent of cerebral amyloid deposition, even before onset of $\mathrm{AD}$ symptoms. $^{20}$

\section{A $\boldsymbol{\beta}$ autoantibodies}

Passive and active immunization against $\mathrm{A} \beta 42$ reduced cerebral amyloid deposition in APP transgenic mice, ${ }^{24,25}$ with suggestive related effects in a human clinical trial of active immunization. ${ }^{26,27}$ Based on these results, it was hypothesized that people possessing autoantibodies against $\mathrm{A} \beta$ would be protected against $\mathrm{AD}$. Autoantibodies against $\mathrm{A} \beta$ were detectable in human plasma and CSF, however titers were similar in $\mathrm{AD}$ and non-AD cases. ${ }^{28,29}$ These studies focused on autoantibodies against monomeric $\mathrm{A} \beta$; it is possible that autoantibodies against oligomeric or aggregated $\mathrm{A} \beta$ are the more clinically relevant species. ${ }^{30}$

$\mathrm{A} \beta$ antibody titers were evaluated as a marker of treatment effectiveness in the clinical trial of $A \beta 42$ (AN1792) immunization for AD. Immunogenicity was followed by anti-A $\beta$ antibody titers, ${ }^{31}$ as well as by the development of antibodies reactive against amyloid deposits in $\mathrm{AD}$ brain tissue. ${ }^{30} \mathrm{In}$ a subgroup from this clinical trial, patients who developed antibodies reactive to amyloid plaques in $\mathrm{AD}$ tissue sections performed better on neuropsychiatric testing than patients who did not develop these antibodies. ${ }^{30}$ Anti-A $\beta$ antibody titers were not predictive of which patients developed subacute meningoencephalitis as a side effect of immunization (18 of 298 on active treatment). ${ }^{31}$

\section{Platelet APP isoforms}

Alterations in the isoform ratios of APP in platelets in AD were reported by two groups. ${ }^{32-34}$ In platelets, 150 $\mathrm{kDa}$ intact APP is processed into $120-130 \mathrm{kDa}$ and 110 $\mathrm{kDa}$ carboxy-truncated forms; all forms can be resolved by Western blot using the antibody $22 \mathrm{C} 11$. The ratio of truncated forms of higher molecular weight (120-130 $\mathrm{kDa}$ ) to the lower molecular weight form ("APP isoform ratio") in platelets was reduced in $\mathrm{AD}$ and mild cognitive impairment, ${ }^{32-34}$ but not in other dementias. ${ }^{33}$ Sensitivities and specificities for AD diagnosis were in the 80 95\% range, based on post hoc cutoff scores. ${ }^{33,34}$ The reduction in the APP isoform ratio correlated with disease severity and progression. ${ }^{33,35}$ Cholesterol reduction, niacin, simvastatin, and cholinesterase inhibitors corrected the abnormally low APP isoform ratios in AD cases. ${ }^{36-38}$ APP isoform ratios inversely correlated with age in one study ${ }^{32}$ but not another ${ }^{33}$; ratios were inde- 
pendent of sex or APOE genotype. ${ }^{32}$ Quantitation of platelet APP isoforms holds promise for tracking diagnosis, progression, and treatment effects. Limitations of the measurement include technique-related factors (tourniquet, anticoagulant, platelet activation), and the Western-blot-based procedure which precludes high throughput and consistent standardization. ${ }^{39}$

\section{MARKERS RELATED TO CHOLESTEROL METABOLISM AND VASCULAR DISEASE}

\section{Cholesterol}

Cardiovascular risk factors including hypertension, $A P O E$ genotype, and cholesterol levels affect $\mathrm{AD}$ risk. ${ }^{40-43}$ High cholesterol levels were associated with an increased risk of $\mathrm{AD}$ or cognitive impairment in several cross-sectional and prospective studies, ${ }^{41,43-45}$ although no association was found in the Framingham cohort, ${ }^{46}$ and established AD cases had lower cholesterol levels in other studies. ${ }^{47,48}$ Cholesterol levels were influenced by APOE genotype, sex, age, and stage of AD. ${ }^{44,49}$ Blood lipids are modifiable by dietary or pharmacologic intervention, and the lipoprotein cholesterol profile is an established marker of the effects of cholesterol-lowering medications and the associated reduction in cardiac risk. Epidemiological data suggest that statins reduce the risk of developing dementia and AD. The relative risk of dementia in statin users was $0.21-0.29$ in case-control studies from the United Kingdom and Canada. ${ }^{50,51} \mathrm{~A}$ protective effect of similar magnitude was found in a review of the databases of three hospitals in the United States. ${ }^{52}$ However, no effect on a secondary measure of incident cognitive decline occurred in a placebo-controlled study of simvastatin for cardiac disease involving 20,536 patients, despite a prominent lipid-lowering benefit. ${ }^{53}$

\section{S-Hydroxycholesterol}

Plasma 24S-hydroxycholesterol reflects brain cholesterol homeostasis more closely than plasma total cholesterol. Excess brain cholesterol is converted to 24S-hydroxycholesterol, a brain-specific oxysterol which readily crosses the blood-brain barrier. ${ }^{54} 24$ S-hydroxycholesterol levels in plasma represent a balance between production in the brain and metabolism in the liver. Plasma levels show a weak, if any, correlation with CSF levels. ${ }^{55,56}$ 24S-hydroxycholesterol was elevated in AD CSF, ${ }^{56,57}$ but was only inconsistently increased in AD plasma. ${ }^{56-58} \mathrm{CSF}$ and plasma 24S-hydroxycholesterol were reduced by statin and niacin treatment. ${ }^{59-61} \mathrm{Al}$ though 24S-hydroxycholesterol is not a diagnostic marker for AD, high levels (similar to high cholesterol levels) may be a modifiable risk factor.

\section{Apolipoprotein E}

The APOE $\epsilon 4$ allele is associated with increased risk of $\mathrm{AD}$, earlier age of $\mathrm{AD}$ onset, increased amyloid plaque load, and elevated levels of $\mathrm{A} \beta 40$ in the $\mathrm{AD}$ brain. ${ }^{62-64}$ The apolipoprotein $\mathrm{E}$ (apoE) phenotype can be determined from plasma by isoelectric focusing or ELISA, ${ }^{65,66}$ although standard APOE genotyping of genomic DNA is easier and as informative regarding $\mathrm{AD}$ risk. ${ }^{67} A P O E$ genotype influences apoE protein levels, with the $A P O E \epsilon 4$ allele being associated with less apoE protein in plasma. ${ }^{68}$ There was no consistent association of serum or plasma apoE protein levels with diagnosis when controlled for $A P O E$ genotype; studies documented elevated apoE levels in $\mathrm{AD},{ }^{69}$ no difference, ${ }^{70-72}$ or reduced levels relative to controls. ${ }^{73,74}$ The ratio of apoE4 protein to apoE3 protein in the plasma of heterozygous $A P O E \in 3 / \epsilon 4$ individuals did not correlate with $\mathrm{AD}$ diagnosis. ${ }^{66}$

\section{Lp(a)}

Lipoprotein $\mathrm{Lp}(\mathrm{a})$ is a low-density lipoprotein-like particle containing the plasminogen-like apolipoprotein (a) linked by disulfide bridge to apolipoprotein B-100. High Lp(a) levels are associated with atherosclerosis, coronary artery disease, and cerebrovascular disease. ${ }^{75}$ Apolipoprotein (a) was detected in primate brain, suggesting that $\mathrm{Lp}$ (a) particles (which can also carry apoE) are involved in cerebral lipoprotein metabolism. ${ }^{76}$ Serum $\mathrm{Lp}$ (a) levels were not associated with cognitive decline over 3 years within an elderly population, ${ }^{77}$ although $\mathrm{AD}$ patients had higher levels of $\mathrm{Lp}(\mathrm{a})$ in a cross-sectional study. $^{48}$

\section{Homocysteine}

Homocysteine is a thiol-containing amino acid involved in the methionine cycle as the demethylation product of methionine (which can subsequently be remethylated in vitamin B12-dependent and folate-dependent processes) and in the transulfuration pathway (in which it is irreversibly converted to cystathione in a vitamin B6-dependent process). ${ }^{78}$ Elevated homocysteine is a risk factor for cardiovascular disease, ${ }^{79}$ and seems to be an independent risk factor for AD. ${ }^{80}$ Hyperhomocystenemia is associated with relative deficiencies of folate, B6, and B12, and with age, male sex, estrogen deficit, renal insufficiency, caffeine use, dopamine agonist use, and anticonvulsant use. The pathophysiology of hyperhomocystenemia and AD risk is unknown, but homocysteine levels are modifiable by vitamin supplementation. $^{78}$

\section{MARKERS OF OXIDATION}

\section{Antioxidant levels}

Increased markers of protein, lipid, and nucleic acid oxidation and reduced activities of antioxidant enzymes in $\mathrm{AD}$ brain support a role for oxidative stress in the neurodegeneration of $\mathrm{AD}{ }^{81,82}$ Antioxidants in plasma include carotene, lycopene, vitamin $\mathrm{A}$, vitamin $\mathrm{C}$, vita- 
min E, urate, and bilirubin. Both vascular dementia and $\mathrm{AD}$ were variably associated with reduced serum or plasma levels of vitamins $\mathrm{A}, \mathrm{C}$, and $\mathrm{E}$, even when controlled for nutritional status. ${ }^{83-87}$ Although vitamin E delayed progression of $\mathrm{AD}$ in one clinical study, ${ }^{88}$ antioxidant vitamin supplementation did not affect incident cognitive impairment over 5 years, as a secondary outcome of a large placebo-controlled cardiac study involving 20,536 individuals. ${ }^{89}$

\section{Lipid peroxidation}

Free radical damage of proteins and polyunsaturated fatty acids results in modified forms that can be measured in fluids as markers of oxidation state. Isoprostanes arise from free-radical-mediated peroxidation of polyunsaturated fatty acids. Isoprostanes were elevated in the brain in a number of diseases, including $\mathrm{AD}$ and Huntington disease. ${ }^{90} \mathrm{~F}_{2}$-isoprostanes were elevated in $\mathrm{AD}$ brain and CSF, with little overlap with control subjects. ${ }^{91-93} \mathrm{~F}_{2}$-isoprostanes were elevated in plasma as well, ${ }^{93,94}$ although this was not confirmed by another group, ${ }^{95}$ perhaps reflecting differences in measurement techniques or cohorts. Plasma isoprostanes are elevated in other illnesses associated with oxidative stress, and can be modified by antioxidant treatment. ${ }^{96}$ 4-hydroxynonenal, another product of lipid peroxidation, was also increased in AD plasma. ${ }^{86}$

\section{MARKERS OF INFLAMMATION}

Amyloid deposition in the $\mathrm{AD}$ brain elicits a range of reactive inflammatory responses including astrocytosis, microgliosis, upregulation of proinflammatory cytokines, complement activation, and acute phase reactions. ${ }^{97}$ Whether the accumulation of cytokines and acute phase reactants within brain is reflected in serum or plasma is not straightforward, because many of these proteins do not easily cross the blood-brain barrier. Alternatively, AD may be associated with a more widespread immune dysregulation, detectable in plasma.

Interpretation of measures of immune mediators in $\mathrm{AD}$ serum and plasma are limited by discordant results. Inflammatory molecules variably increased in $\mathrm{AD}$ include C-reactive protein, interleukin (IL)- $1 \beta$, tumor necrosis factor- $\alpha$, IL-6, IL-6 receptor complex, $\alpha 1$-antichymotrypsin, and transforming growth factor- $\beta$; these were unchanged in other studies, as were other cytokines including IL-12, interferon- $\alpha$, and interferon- $\gamma .{ }^{98}$

IL-6, for example, has been extensively studied in AD. IL-6 is a cytokine implicated in inflammation, acute phase responses, and cell proliferation whose effects are mediated by a receptor complex including the IL- 6 receptor $\alpha$-subunit and glycoprotein 130. Several groups reported increased IL-6 in AD plasma or serum, ${ }^{99,100-104}$ although this was not the case in other cohorts. ${ }^{105-108}$ Con- founding factors in these studies of inflammatory markers include differences in plasma collection protocols, assay methodology, assay sensitivity, small sample sizes, heterogeneous patient populations, effects of disease severity, ${ }^{103}$ age, ${ }^{109}$ and comorbid inflammatory illness.

\section{BIOMARKER PROFILING}

Given the multiplicity of pathophysiological processes implicated in $\mathrm{AD}$, the diagnostic accuracy of biomarkers may be improved by combining several serum or plasma markers, ${ }^{110}$ thereby creating a more robust biomarker profile characteristic of AD. Approaches to biomarker profiling can be "knowledge-based," incorporating the range of known putative AD biomarkers, or "unbiased," surveying hundreds or thousands of biomolecules using proteomic or metabolomic methods to discover novel molecular profiles representative of AD. The knowledgebased approach, which attempts to use as much of the known data regarding molecules implicated in $\mathrm{AD}$, is exemplified by a study of $34 \mathrm{AD}, 46$ Parkinson disease, 47 patients with other cognitive disorders, and 61 controls that examined a panel of 29 serum biomarkers for inflammation, homocysteine metabolism, cholesterol metabolism, and brain-specific proteins. A model incorporating IL- 6 receptor, cysteine, protein fraction $\alpha 1$ and cholesterol levels was superior to individual markers in discriminating $\mathrm{AD}$ from controls, although specificity relative to other neurological illnesses was weaker. ${ }^{110}$ Confirmation in larger populations and incorporation of additional markers of amyloid metabolism and oxidative stress may improve sensitivity and specificity.

Large-scale unbiased approaches evaluate a broad range of proteins ("proteomics") or small molecule metabolites ("metabolomics") in biological fluids. Proteomics methodologies include: separation of proteins by 2-dimensional polyacrylamide gel electrophoresis (2DPAGE) or HPLC ${ }^{111}$; surface chromatography by adsorbing proteins to activated surfaces (surface-enhanced or matrix-assisted laser desorption-ionization protein chip array technology) ${ }^{112}$; and peptide ionization procedures for analysis of proteins from gels or protein chips by mass spectroscopy. A 2D-PAGE study detected 350 silver-stained proteins in the plasma of six control cases, five $\mathrm{AD}$ cases, and three non-AD dementias, of which 73 spots were identified by sequencing or immunostaining, including the AD-related proteins apoE, tau, and presenilin-2. ${ }^{113}$ The complexity of serum and plasma, imprecision of peak matching in mass spectroscopy and spot matching in 2D-PAGE, and difficulties in assay standardization make these approaches challenging, but advances in technology platforms and bioinformatics will allow broader applicability to diseases such as AD. ${ }^{114}$ 


\section{CONCLUSIONS}

Studies of plasma and serum biomarkers have not yielded a consistent, easily reproducible, sensitive, or specific marker for $\mathrm{AD}$ diagnosis, risk, progression, or treatment effects. Measures of APP metabolism, inflammation, cholesterol metabolism, oxidative stress, and homocysteine homeostasis appear to be altered in AD relative to controls, but without sufficient discriminatory power. Several measures are responsive to medications, for instance statins reduce cholesterol and 24S-hydroxycholesterol levels, folate reduces homocysteine levels, and $\mathrm{A} \beta$ immunization produces anti- $\mathrm{A} \beta$ antibodies. However, a consistent correlation with clinical benefit must be convincingly demonstrated before any measure can be recommended as a surrogate marker in clinical trials (as opposed to being merely markers for the mechanism of drug action.) Omnibus measures combining several biomarkers or incorporating proteomic and metabolomic profiles are promising approaches for the development of plasma or serum-based diagnostic tests for $\mathrm{AD}$.

Acknowledgments: This work was supported by National Institutes of Health Grants AG05134 (Massachusetts Alzheimer's Disease Research Center, Boston, MA) and AG004953, and a Beeson Award from the American Federation of Aging Research.

We thank Michael Gillette (Broad Institute, Cambridge, MA) for contributions regarding the promise and limitations of proteomics in biomarker development.

\section{REFERENCES}

1. The Ronald and Nancy Reagan Research Institute of the Alzheimer's Association and the National Institute on Aging Working Group. Consensus report of the Working Group on: Molecular and biochemical markers of Alzheimer's disease. Neurobiol Aging 19:109-116, 1998.

2. Gravina SA, Ho L, Eckman CB, Long KE, Otvos LJ, Younkin LH et al. Amyloid $\beta$ protein $(\mathrm{A} \beta)$ in Alzheimer's disease brain. Biochemical and immunocytochemical analysis with antibodies specific for forms ending at $\mathrm{A} \beta 40$ or $\mathrm{A} \beta$ 42(43). J Biol Chem 270:7013-7016, 1995.

3. Fukumoto H, Asami-Odaka A, Suzuki N, Shimada H, Ihara Y, Iwatsubo T. Amyloid $\beta$ protein deposition in normal aging has the same characteristics as that in Alzheimer's disease. Predominance of $\mathrm{A} \beta 42(43)$ and association of $\mathrm{A} \beta 40$ with cored plaques. Am J Pathol 148:259-265, 1996.

4. Jarrett JT, Berger EP, Lansbury PT Jr. The carboxy terminus of the $\beta$ amyloid protein is critical for the seeding of amyloid formation: implications for the pathogenesis of Alzheimer's disease. Biochemistry 32:4693-4697, 1993.

5. Scheuner D, Eckman C, Jensen M, Song X, Citron M, Suzuki N et al. Secreted amyloid $\beta$-protein similar to that in the senile plaques of Alzheimer's disease is increased in vivo by the presenilin 1 and 2 and APP mutations linked to familial Alzheimer's disease. Nat Med 2:864-870, 1996.

6. Kosaka T, Imagawa M, Seki K, Arai H, Sasaki H, Tsuji S et al. The $\beta$ APP717 Alzheimer mutation increases the percentage of plasma amyloid- $\beta$ protein ending at $\mathrm{A} \beta 42(43)$. Neurology 48: 741-745, 1997.

7. Schupf N, Patel B, Silverman W, Zigman WB, Zhong N, Tycko $\mathrm{B}$ et al. Elevated plasma amyloid $\beta$-peptide $1-42$ and onset of dementia in adults with Down syndrome. Neurosci Lett 301:199_ 203, 2001.

8. Tamaoka A, Fukushima T, Sawamura N, Ishikawa K, Oguni E, Komatsuzaki $Y$ et al. Amyloid $\beta$ protein in plasma from patients with sporadic Alzheimer's disease. J Neurol Sci 141:65-68, 1996.

9. Mayeux R, Tang MX, Jacobs DM, Manly J, Bell K, Merchant C et al. Plasma amyloid $\beta$-peptide 1-42 and incipient Alzheimer's disease. Ann Neurol 46:412-416, 1999.

10. Mehta PD, Pirttila T, Mehta SP, Sersen EA, Aisen PS, Wisniewski HM. Plasma and cerebrospinal fluid levels of amyloid $\beta$ proteins 1-40 and 1-42 in Alzheimer disease. Arch Neurol 57:100-105, 2000.

11. Vanderstichele H, Van Kerschaver E, Hesse C, Davidsson P, Buyse MA, Andreasen N et al. Standardization of measurement of $\beta$-amyloid(1-42) in cerebrospinal fluid and plasma. Amyloid 7:245-258, 2000.

12. Fukumoto H, Tennis M, Locascio JJ, Hyman BT, Growdon JH, Irizarry MC. Age but not diagnosis is the main predictor of plasma amyloid $\beta$-protein levels. Arch Neurol 60:958-964, 2003.

13. Mayeux R, Honig LS, Tang MX, Manly J, Stern Y, Schupf N et al. Plasma $A \beta 40$ and $A \beta 42$ and Alzheimer's disease: relation to age, mortality, and risk. Neurology 61:1185-1190, 2003.

14. Younkin SG, Eckman CB, Ertekin-Taner N, Kawarabayashi T, Yager D, Baker M et al. Genetic elevation of plasma amyloid $\beta$ protein in typical late onset Alzheimer's disease. Soc Neurosci Abstr 24:263, 1998.

15. Arvanitakis Z, Lucas JA, Younkin LH, Younkin SG, Graff-Radford NR. Serum creatinine levels correlate with plasma amyloid $\beta$ protein. Alzheimer Dis Assoc Disord 16:187-190, 2002.

16. Mehta PD, Pirttila T, Patrick BA, Barshatzky M, Mehta SP. Amyloid $\beta$ protein $1-40$ and 1-42 levels in matched cerebrospinal fluid and plasma from patients with Alzheimer disease. Neurosci Lett 304:102-106, 2001.

17. Tokuda T, Tamaoka A, Matsuno S, Sakurai S, Shimada H, Morita $\mathrm{H}$ et al. Plasma levels of amyloid $\beta$ proteins did not differ between subjects taking statins and those not taking statins. Ann Neurol 49:546-547, 2001.

18. Buxbaum JD, Cullen EI, Friedhoff LT. Pharmacological concentrations of the HMG-CoA reductase inhibitor lovastatin decrease the formation of the Alzheimer $\beta$-amyloid peptide in vitro and in patients. Front Biosci 7:a50-59, 2002.

19. Baker LD, Sambamurti K, Craft S, Cherrier M, Raskind MA, Stanczyk FZ et al. $17 \beta$-Estradiol reduces plasma A $\beta 40$ for HRTnaive postmenopausal women with Alzheimer disease: a preliminary study. Am J Geriatr Psychiatry 11:239-244, 2003.

20. DeMattos RB, Bales KR, Cummins DJ, Paul SM, Holtzman DM. Brain to plasma amyloid- $\beta$ efflux: a measure of brain amyloid burden in a mouse model of Alzheimer's disease. Science 295: 2264-2267, 2002.

21. Ghersi-Egea JF, Gorevic PD, Ghiso J, Frangione B, Patlak CS, Fenstermacher JD. Fate of cerebrospinal fluid-borne amyloid $\beta$-peptide: rapid clearance into blood and appreciable accumulation by cerebral arteries. J Neurochem 67:880-883, 1996.

22. Maness LM, Banks WA, Podlisny MB, Selkoe DJ, Kastin AJ. Passage of human amyloid $\beta$-protein 1-40 across the murine blood-brain barrier. Life Sci 55:1643-1650, 1994.

23. Matsuoka Y, Saito M, LaFrancois J, Gaynor K, Olm V, Wang L et al. Novel therapeutic approach for the treatment of Alzheimer's disease by peripheral administration of agents with an affinity to beta-amyloid. J Neurosci 23:29-33, 2003.

24. Schenk D, Barbour R, Dunn W, Gordon G, Grajeda H, Guido T et al. Immunization with amyloid- $\beta$ attenuates Alzheimer-disease-like pathology in the PDAPP mouse. Nature 400:173-177, 1999.

25. Bard F, Cannon C, Barbour R, Burke RL, Games D, Grajeda H et al. Peripherally administered antibodies against amyloid betapeptide enter the central nervous system and reduce pathology in a mouse model of Alzheimer disease. Nat Med 6:916-919, 2000.

26. Nicoll JA, Wilkinson D, Holmes C, Steart P, Markham H, Weller RO. Neuropathology of human Alzheimer disease after immunization with amyloid- $\beta$ peptide: a case report. Nat Med 9:448452, 2003. 
27. Hock C, Konietzko U, Papassotiropoulos A, Wollmer A, Streffer $\mathrm{J}$, von Rotz RC et al. Generation of antibodies specific for $\beta$-amyloid by vaccination of patients with Alzheimer disease. Nat Med 8:1270-1275, 2002.

28. Du Y, Dodel R, Hampel H, Buerger K, Lin S, Eastwood B et al. Reduced levels of amyloid $\beta$-peptide antibody in Alzheimer disease. Neurology 57:801-805, 2001.

29. Hyman BT, Smith C, Buldyrev I, Whelan C, Brown H, Tang MX et al. Autoantibodies to amyloid- $\beta$ and Alzheimer's disease. Ann Neurol 49:808-810, 2001.

30. Hock C, Konietzko U, Streffer JR, Tracy J, Signorell A, MullerTillmanns $\mathrm{B}$ et al. Antibodies against $\beta$-amyloid slow cognitive decline in Alzheimer's disease. Neuron 38:547-554, 2003.

31. Orgogozo JM, Gilman S, Dartigues JF, Laurent B, Puel M, Kirby LC et al. Subacute meningoencephalitis in a subset of patients with AD after A $\beta 42$ immunization. Neurology 61:46-54, 2003.

32. Rosenberg RN, Baskin F, Fosmire JA, Risser R, Adams P, Svetlik $\mathrm{D}$ et al. Altered amyloid protein processing in platelets of patients with Alzheimer disease. Arch Neurol 54:139-144, 1997.

33. Padovani A, Pastorino L, Borroni B, Colciaghi F, Rozzini L, Monastero $\mathrm{R}$ et al. Amyloid precursor protein in platelets: a peripheral marker for the diagnosis of sporadic AD. Neurology 57:2243-2248, 2001.

34. Padovani A, Borroni B, Colciaghi F, Pettenati C, Cottini E, Agosti $\mathrm{C}$ et al. Abnormalities in the pattern of platelet amyloid precursor protein forms in patients with mild cognitive impairment and Alzheimer disease. Arch Neurol 59:71-75, 2002.

35. Baskin F, Rosenberg RN, Iyer L, Hynan L, Cullum CM. Platelet APP isoform ratios correlate with declining cognition in AD. Neurology 54:1907-1909, 2000.

36. Borroni B, Colciaghi F, Pastorino L, Pettenati C, Cottini E, Rozzini L et al. Amyloid precursor protein in platelets of patients with Alzheimer disease: effect of acetylcholinesterase inhibitor treatment. Arch Neurol 58:442-446, 2001.

37. Baskin F, Rosenberg RN, Fang X, Hynan LS, Moore CB, Weiner $\mathrm{M}$ et al. Correlation of statin-increased platelet APP ratios and reduced blood lipids in AD patients. Neurology 60:2006-2007, 2003.

38. Borroni B, Colciaghi F, Lenzi GL, Caimi L, Cattabeni F, Di Luca $\mathrm{M}$ et al. High cholesterol affects platelet APP processing in controls and in AD patients. Neurobiol Aging 24:631-636, 2003.

39. Bush AI, Tanzi RE. Alzheimer disease-related abnormalities of amyloid $\beta$ precursor protein isoforms in the platelet: the brain's delegate in the periphery? Arch Neurol 55:1179-1180, 1998.

40. Birkenhager WH, Forette F, Seux ML, Wang JG, Staessen JA. Blood pressure, cognitive functions, and prevention of dementias in older patients with hypertension. Arch Intern Med 161:152156, 2001.

41. Notkola IL, Sulkava R, Pekkanen J, Erkinjuntti T, Ehnholm C, Kivinen $\mathrm{P}$ et al. Serum total cholesterol, apolipoprotein E epsilon 4 allele, and Alzheimer's disease. Neuroepidemiology 17:14-20, 1998.

42. Hofman A, Ott A, Breteler MM, Bots ML, Slooter AJ, van Harskamp F et al. Atherosclerosis, apolipoprotein E, and prevalence of dementia and Alzheimer's disease in the Rotterdam Study. Lancet 349:151-154, 1997.

43. Kivipelto M, Helkala EL, Laakso MP, Hanninen T, Hallikainen $\mathrm{M}$, Alhainen $\mathrm{K}$ et al. Midlife vascular risk factors and Alzheimer's disease in later life: longitudinal, population-based study. BMJ 322:1447-1451, 2001.

44. Evans RM, Emsley CL, Gao S, Sahota A, Hall KS, Farlow MR et al. Serum cholesterol, APOE genotype, and the risk of Alzheimer's disease: a population-based study of African Americans. Neurology 54:240-242, 2000.

45. Yaffe K, Barrett-Connor E, Lin F, Grady D. Serum lipoprotein levels, statin use, and cognitive function in older women. Arch Neurol 59:378-384, 2002.

46. Tan ZS, Seshadri S, Beiser A, Wilson PW, Kiel DP, Tocco M et al. Plasma total cholesterol level as a risk factor for Alzheimer disease: the Framingham Study. Arch Intern Med 163:1053-1057, 2003.

47. Romas SN, Tang MX, Berglund L, Mayeux R. APOE genotype, plasma lipids, lipoproteins, and AD in community elderly. Neurology 53:517-521, 1999.
48. Solfrizzi V, Panza F, D’Introno A, Colacicco AM, Capurso C, Basile AM et al. Lipoprotein(a), apolipoprotein E genotype, and risk of Alzheimer's disease. J Neurol Neurosurg Psychiatry 72: 732-736, 2002.

49. Jarvik GP, Wijsman EM, Kukull WA, Schellenberg GD, Yu C, Larson EB. Interactions of apolipoprotein E genotype, total cholesterol level, age, and sex in prediction of Alzheimer's disease: a case-control study. Neurology 45:1092-1096, 1995.

50. Jick H, Zornberg GL, Jick SS, Seshadri S, Drachman DA. Statins and the risk of dementia. Lancet 356:1627-1631, 2000.

51. Rockwood K, Kirkland S, Hogan DB, MacKnight C, Merry H, Verreault $\mathrm{R}$ et al. Use of lipid-lowering agents, indication bias, and the risk of dementia in community-dwelling elderly people. Arch Neurol 59:223-227, 2002.

52. Wolozin B, Kellman W, Ruosseau P, Celesia GG, Siegel G. Decreased prevalence of Alzheimer disease associated with 3-hydroxy-3-methylglutaryl coenzyme A reductase inhibitors. Arch Neurol 52:1439-1443, 2000.

53. Heart Protection Study Collaborative Group. MRC/BHF heart protection study of cholesterol lowering with simvastatin in 20,536 high-risk individuals: a randomised placebo-controlled trial. Lancet 360:7-22, 2002.

54. Dietschy JM, Turley SD. Cholesterol metabolism in the brain. Curr Opin Lipidol 12:105-112, 2001.

55. Leoni V, Masterman T, Patel P, Meaney S, Diczfalusy U, Bjorkhem I. Side chain oxidized oxysterols in cerebrospinal fluid and the integrity of blood-brain and blood-cerebrospinal fluid barriers. J Lipid Res 44:793-799, 2003.

56. Papassotiropoulos A, Lutjohann D, Bagli M, Locatelli S, Jessen $\mathrm{F}$, Buschfort $\mathrm{R}$ et al. 24S-hydroxycholesterol in cerebrospinal fluid is elevated in early stages of dementia. $J$ Psychiatr Res 36:27-32, 2002.

57. Schonknecht P, Lutjohann D, Pantel J, Bardenheuer H, Hartmann $\mathrm{T}$, von Bergmann $\mathrm{K}$ et al. Cerebrospinal fluid 24S-hydroxycholesterol is increased in patients with Alzheimer's disease compared to healthy controls. Neurosci Lett 324:83-85, 2002.

58. Lutjohann D, Papassotiropoulos A, Bjorkhem I, Locatelli S, Bagli M, Oehring RD et al. Plasma 24S-hydroxycholesterol (cerebrosterol) is increased in Alzheimer and vascular demented patients. J Lipid Res 41:195-198, 2000.

59. Simons M, Schwarzler F, Lutjohann D, von Bergmann K, Beyreuther K, Dichgans J et al. Treatment with simvastatin in normocholesterolemic patients with Alzheimer's disease: a 26 week randomized, placebo-controlled, double-blind trial. Ann Neurol 52:346-350, 2002.

60. Locatelli S, Lutjohann D, Schmidt HH, Otto C, Beisiegel U, von Bergmann K. Reduction of plasma 24S-hydroxycholesterol (cerebrosterol) levels using high-dosage simvastatin in patients with hypercholesterolemia: evidence that simvastatin affects cholesterol metabolism in the human brain. Arch Neurol 59:213-216, 2002.

61. Vega GL, Weiner MF, Lipton AM, Von Bergmann K, Lutjohann $\mathrm{D}$, Moore $\mathrm{C}$ et al. Reduction in levels of 24S-hydroxycholesterol by statin treatment in patients with Alzheimer disease. Arch Neurol 60:510-515, 2003.

62. Saunders A, Strittmater W, Schmechel D, St. George-Hyslop P, Pericak-Vance M, Joo S et al. Association of apolipoprotein E allele $\epsilon 4$ with late-onset familial and sporadic Alzheimer's disease. Neurology 43:1467-1472, 1993.

63. Gomez-Isla T, West HL, Rebeck GW, Harr SD, Growdon JH, Locasio JT et al. Clinical and pathological correlates of apolipoprotein E $\epsilon 4$ in Alzheimer's disease. Ann Neurol 39:62-70, 1996.

64. Mann DM, Iwatsubo T, Pickering-Brown SM, Owen F, Saido TC, Perry RH. Preferential deposition of amyloid beta protein $(\mathrm{A} \beta)$ in the form $\mathrm{A} \beta 40$ in Alzheimer's disease is associated with a gene dosage effect of the apolipoprotein E $\epsilon 4$ allele. Neurosci Lett 221:81-84, 1997.

65. Ordovas JM, Litwack-Klein L, Wilson PW, Schaefer MM, Schaefer EJ. Apolipoprotein E isoform phenotyping methodology and population frequency with identification of apoE1 and apoE5 isoforms. J Lipid Res 28:371-380, 1987.

66. Fukumoto H, Ingelsson M, Garevik N, Wahlund LO, Nukina N, 
Yaguchi Y et al. APOE epsilon 3/epsilon 4 heterozygotes have an elevated proportion of apolipoprotein E4 in cerebrospinal fluid relative to plasma, independent of Alzheimer's disease diagnosis. Exp Neurol 183:249-253, 2003.

67. Ingelsson M, Lilius L, Forsell C, Shin Y, Irizarry M, Graff C et al. Genotyping of apolipoprotein E: comparative evaluation of different protocols. Curr Prot Hum Genet Unit 9.14, 2003.

68. Schiele F, De Bacquer D, Vincent-Viry M, Beisiegel U, Ehnholm C, Evans A et al. Apolipoprotein E serum concentration and polymorphism in six European countries: the ApoEurope Project. Atherosclerosis 152:475-488, 2000.

69. Taddei K, Clarnette R, Gandy SE, Martins RN. Increased plasma apolipoprotein E (apoE) levels in Alzheimer's disease. Neurosci Lett 223:29-32, 1997.

70. Scacchi R, Gambina G, Ruggeri M, Martini MC, Ferrari G, Silvestri $\mathrm{M}$ et al. Plasma levels of apolipoprotein $\mathrm{E}$ and genetic markers in elderly patients with Alzheimer's disease. Neurosci Lett 259:33-36, 1999.

71. Slooter AJ, de Knijff P, Hofman A, Cruts M, Breteler MM, Van Broeckhoven $\mathrm{C}$ et al. Serum apolipoprotein E level is not increased in Alzheimer's disease: the Rotterdam study. Neurosci Lett 248:21-24, 1998.

72. Panza F, Solfrizzi V, Colacicco AM, Basile AM, D'Introno A, Capurso C, et al. Apolipoprotein E (APOE) polymorphism influences serum APOE levels in Alzheimer's disease patients and centenarians. NeuroReport 14:605-608, 2003.

73. Lehtimaki T, Pirttila T, Mehta PD, Wisniewski HM, Frey H, Nikkari T. Apolipoprotein E (apoE) polymorphism and its influence on ApoE concentrations in the cerebrospinal fluid in Finnish patients with Alzheimer's disease. Hum Genet 95:39-42, 1995.

74. Siest G, Bertrand P, Qin B, Herbeth B, Serot JM, Masana L et al. Apolipoprotein E polymorphism and serum concentration in Alzheimer's disease in nine European centres: the ApoEurope study. ApoEurope group. Clin Chem Lab Med 38:721-730, 2000.

75. Milionis HJ, Winder AF, Mikhailidis DP. Lipoprotein (a) and stroke. J Clin Pathol 53:487-496, 2000.

76. Ramharack R, Spahr MA, Kreick JS, Sekerke CS. Expression of apolipoprotein (a) and plasminogen mRNAs in cynomolgus monkey liver and extrahepatic tissues. J Lipid Res 37:2029-2040, 1996.

77. Sarti C, Pantoni L, Pracucci G, Di Carlo A, Vanni P, Inzitari D. Lipoprotein(a) and cognitive performances in an elderly white population: cross-sectional and follow-up data. Stroke 32:16781683, 2001.

78. Diaz-Arrastia R. Homocysteine and neurologic disease. Arch Neurol 57:1422-1427, 2000.

79. Boushey CJ, Beresford SA, Omenn GS, Motulsky AG. A quantitative assessment of plasma homocysteine as a risk factor for vascular disease. Probable benefits of increasing folic acid intakes. JAMA 274:1049-1057, 1995.

80. Seshadri S, Beiser A, Selhub J, Jacques PF, Rosenberg IH, D'Agostino RB et al. Plasma homocysteine as a risk factor for dementia and Alzheimer's disease. N Engl J Med 346:476-483, 2002.

81. Bonilla E, Tanji K, Hirano M, Vu TH, DiMauro S, Schon EA. Mitochondrial involvement in Alzheimer's disease. Biochim Biophys Acta 1410:171-182, 1999.

82. Butterfield DA, Castegna A, Lauderback CM, Drake J. Evidence that amyloid $\beta$-peptide-induced lipid peroxidation and its sequelae in Alzheimer's disease brain contribute to neuronal death. Neurobiol Aging 23:655-664, 2002.

83. Zaman Z, Roche S, Fielden P, Frost PG, Niriella DC, Cayley AC. Plasma concentrations of vitamins $\mathrm{A}$ and $\mathrm{E}$ and carotenoids in Alzheimer's disease. Age Ageing 21:91-94, 1992.

84. Jeandel C, Nicolas MB, Dubois F, Nabet-Belleville F, Penin F, Cuny G. Lipid peroxidation and free radical scavengers in Alzheimer's disease. Gerontology 35:275-282, 1989.

85. Foy CJ, Passmore AP, Vahidassr MD, Young IS, Lawson JT. Plasma chain-breaking antioxidants in Alzheimer's disease, vascular dementia and Parkinson's disease. QJM 92:39-45, 1999.

86. McGrath LT, McGleenon BM, Brennan S, McColl D, McIlroy S, Passmore AP. Increased oxidative stress in Alzheimer's disease as assessed with 4-hydroxynonenal but not malondialdehyde. QJM 94:485-490, 2001.

87. Polidori MC, Mecocci P. Plasma susceptibility to free radicalinduced antioxidant consumption and lipid peroxidation is increased in very old subjects with Alzheimer disease. J Alzheimers Dis 4:517-522, 2002.

88. Sano M, Ernesto C, Thomas RG, Klauber MR, Schafer K, Grundman M, et al. A controlled trial of selegiline, alpha-tocopherol, or both as treatment for Alzheimer's disease. The Alzheimer's Disease Cooperative Study. N Engl J Med 336:1216-1222, 1997.

89. Heart Protection Study Collaborative Group. MRC/BHF heart protection study of antioxidant vitamin supplementation in 20,536 high-risk individuals: a randomised placebo-controlled trial. Lancet 360:23-33, 2002.

90. Greco A, Minghetti L, Levi G. Isoprostanes, novel markers of oxidative injury, help understanding the pathogenesis of neurodegenerative diseases. Neurochem Res 25:1357-1364, 2000.

91. Pratico D, Lee VM-Y, Trojanowski JQ, Rokach J, Fitzgerald GA. Increased F2-isoprostanes in Alzheimer's disease: evidence for enhanced lipid peroxidation in vivo. FASEB $J$ 12:1777-1783, 1998.

92. Montine TJ, Beal MF, Cudkowicz ME, O'Donnell H, Margolin RA, McFarland L et al. Increased CSF F2-isoprostane concentration in probable AD. Neurology 52:562-565, 1999.

93. Pratico D, Clark CM, Lee VM, Trojanowski JQ, Rokach J, FitzGerald GA. Increased 8,12-iso-iPF2alpha-VI in Alzheimer's disease: correlation of a noninvasive index of lipid peroxidation with disease severity. Ann Neurol 48:809-812, 2000.

94. Pratico D, Clark CM, Liun F, Rokach J, Lee VY, Trojanowski JQ. Increase of brain oxidative stress in mild cognitive impairment: a possible predictor of Alzheimer disease. Arch Neurol 59:972976, 2002.

95. Montine TJ, Quinn JF, Milatovic D, Silbert LC, Dang T, Sanchez $\mathrm{S}$ et al. Peripheral F2-isoprostanes and F4-neuroprostanes are not increased in Alzheimer's disease. Ann Neurol 52:175-179, 2002.

96. Cracowski JL, Durand T, Bessard G. Isoprostanes as a biomarker of lipid peroxidation in humans: physiology, pharmacology and clinical implications. Trends Pharmacol Sci 23:360-366, 2002.

97. Weiner HL, Selkoe DJ. Inflammation and therapeutic vaccination in CNS diseases. Nature 420:879-884, 2002.

98. Teunissen CE, de Vente J, Steinbusch HW, De Bruijn C. Biochemical markers related to Alzheimer's dementia in serum and cerebrospinal fluid. Neurobiol Aging 23:485-508, 2002.

99. Licastro F, Pedrini S, Caputo L, Annoni G, Davis LJ, Ferri C et al. Increased plasma levels of interleukin-1, interleukin-6 and $\alpha$-1-antichymotrypsin in patients with Alzheimer's disease: peripheral inflammation or signals from the brain? J Neuroimmunol 103:97-102, 2000.

100. Singh VK, Guthikonda P. Circulating cytokines in Alzheimer's disease. J Psychiatr Res 31:657-660, 1997.

101. Tarkowski E, Blennow K, Wallin A, Tarkowski A. Intracerebral production of tumor necrosis factor- $\alpha$, a local neuroprotective agent, in Alzheimer disease and vascular dementia. J Clin Immunol 19:223-230, 1999.

102. Maes M, DeVos N, Wauters A, Demedts P, Maurits VW, Neels $\mathrm{H}$ et al. Inflammatory markers in younger vs elderly normal volunteers and in patients with Alzheimer's disease. J Psychiatr Res 33:397-405, 1999.

103. Kalman J, Juhasz A, Laird G, Dickens P, Jardanhazy T, Rimanoczy A et al. Serum interleukin-6 levels correlate with the severity of dementia in Down syndrome and in Alzheimer's disease. Acta Neurol Scand 96:236-240, 1997.

104. Bonaccorso S, Lin A, Song C, Verkerk R, Kenis G, Bosmans E et al. Serotonin-immune interactions in elderly volunteers and in patients with Alzheimer's disease (DAT): lower plasma tryptophan availability to the brain in the elderly and increased serum interleukin-6 in DAT. Aging (Milano) 10:316-323, 1998.

105. Blum-Degen D, Muller T, Kuhn W, Gerlach M, Przuntek H, Riederer P. Interleukin- $1 \beta$ and interleukin- 6 are elevated in the cerebrospinal fluid of Alzheimer's and de novo Parkinson's disease patients. Neurosci Lett 202:17-20, 1995. 
106. Angelis P, Scharf S, Mander A, Vajda F, Christophidis N. Serum interleukin-6 and interleukin-6 soluble receptor in Alzheimer's disease. Neurosci Lett 244:106-108, 1998.

107. Chao CC, Ala TA, Hu S, Crossley KB, Sherman RE, Peterson PK, et al. Serum cytokine levels in patients with Alzheimer's disease. Clin Diagn Lab Immunol 1:433-436, 1994.

108. van Duijn CM, Hofman A, Nagelkerken L. Serum levels of interleukin- 6 are not elevated in patients with Alzheimer's disease. Neurosci Lett 108:350-354, 1990.

109. Ershler WB, Sun WH, Binkley N, Gravenstein S, Volk MJ, Kamoske G, et al. Interleukin-6 and aging: blood levels and mononuclear cell production increase with advancing age and in vitro production is modifiable by dietary restriction. Lymphokine Cytokine Res 12:225-230, 1993.

110. Teunissen CE, Lutjohann D, von Bergmann K, Verhey F, Vreeling $\mathrm{F}$, Wauters $\mathrm{A}$ et al. Combination of serum markers related to several mechanisms in Alzheimer's disease. Neurobiol Aging 24:893-902, 2003.

111. Butterfield DA, Boyd-Kimball D, Castegna A. Proteomics in Alzheimer's disease: insights into potential mechanisms of neurodegeneration. J Neurochem 86:1313-1327, 2003.

112. Carrette O, Demalte I, Scherl A, Yalkinoglu O, Corthals G, Burkhard $\mathrm{P}$ et al. A panel of cerebrospinal fluid potential biomarkers for the diagnosis of Alzheimer's disease. Proteomics 3:1486-1494, 2003.

113. Ueno I, Sakai T, Yamaoka M, Yoshida R, Tsugita A. Analysis of blood plasma proteins in patients with Alzheimer's disease by two-dimensional electrophoresis, sequence homology and immunodetection. Electrophoresis 21:1832-1845, 2000.

114. Frank R, Hargreaves R. Clinical biomarkers in drug discovery and development. Nat Rev Drug Discov 2:566-580, 2003. 